\title{
Modern Concepts on Diamond Genesis
}

\author{
F. V. Kaminsky ${ }^{a, *}$ and S. A. Voropaev ${ }^{a, * *}$ \\ ${ }^{a}$ Vernadsky Institute of Geochemistry and Analytical Chemistry, Russian Academy of Science, Moscow, 119991 Russia \\ *e-mail: kaminsky@geokhi.ru \\ **e-mail:voropaev@geokhi.ru \\ Received April 14, 2021; revised April 20, 2021; accepted April 22, 2021
}

\begin{abstract}
The best-known, most well-studied diamondiferous rocks are kimberlites and lamproites. Diamonds are also found in impactites, metamorphic rocks, ophiolites, and modern volcanic rocks. Diamonds from these rocks differ from kimberlitic diamonds in size, morphology, trace-element and isotope composition, and physical properties. Differences in these characteristics are related to their different mechanisms of origin. In some cases, diamonds can be formed in "metastable" conditions under disequilibrium thermodynamic parameters, supporting the conclusion that diamond is a polygenetic mineral, formed in nature under different physicochemical and geodynamic conditions. According to thermodynamic considerations and calculations, "metastable" crystallization of diamond is mainly controlled by the size of the forming crystallites. The main effectors in decreasing the energetic barrier for nanosized diamonds are surface tension and related surface energy.
\end{abstract}

Keywords: diamond, genesis, kimberlites, lamproites, ophiolites, chromitites, impactites, phase transitions DOI: $10.1134 / \mathrm{S} 0016702921110033$

\section{INTRODUCTION}

For several decades, monographs "Diamond Genesis" (Williams, 1932) and "Diamond Fields of South Africa (Wagner, 1914) have been the main sources of data on diamond geology and the genesis of diamonds. Later publications were dedicated to diamonds from placer deposits in India, Indonesia, Southeast Australia, Brazil, and Urals. Diamonds were well known to be found in these deposits before the discovery of South African diamonds, but were thought to be unrelated to kimberlites. Several reviews that have considered these data have been published in the USSR (Sobolev, 1951; Kukharenko, 1955; Trofimov, 1980) and France (Bardet, 1973, 1974, 1977). Throughout 1950 s to the 1990 s, diamondiferous kimberlites were found on all continents, including practically all ancient cratons in Siberia, North America, Australia, China, and Brazil (Fig. 1). Studies have shown that diamonds in kimberlites are formed at large mantle depths under high temperatures and pressures. Concepts regarding diamond genesis based on existing research have been summarized in a publication by V.S. Sobolev (1960), which has served as a basis for further scientific developments for many years.

Of special significance were studies of deep-seated mineral inclusions entrapped during diamond formation, which represent means of probing parental mantle rocks and provide insights into conditions during diamond formation (Sobolev, 1974; Meyer, 1987). It has been established that diamonds can be formed in the upper mantle at depths greater than $150 \mathrm{~km}$. Together with data on xenoliths in alkaline basalts, this knowledge has made it possible for the first time to study upper mantle materials, leading to the conclusion that primary diamond sources are not kimberlites but diamondiferous peridotites and eclogites, which comprise deep mantle horizons, and are destructed to supply diamonds to kimberlites originating in these rocks.

Geochemical studies, first of all, determination of carbon isotope composition in diamonds, are also of great significance. Single measurements conducted by Craig, Wickman, and Vinogradov have been continued and developed in a detailed study by Galimov et al. (1978). Galimov et al. revealed, for the first time, carbon isotope zoning and wide variations in carbon isotope composition in diamond crystals (Galimov, 1984). Studies of carbon isotope composition in diamond is a powerful tool for studies of diamond genesis (Sobolev et al., 1979; Galimov, 1984).

In the next stage of research, diamonds were discovered in a wide variety of non-kimberlitic igneous rocks, including alkaline basalts, picrites, and ultrabasic lamprophyres. The large number of these finds, including in situ in different rocks, indicates that this is a natural phenomenon (Kaminsky, 1984). High economic diamond deposits have been discovered in lamproites of the Argyle and Ellendale mines in Western Australia (Jaques et al., 1986). Some diamond deposits in North America and India have also been 


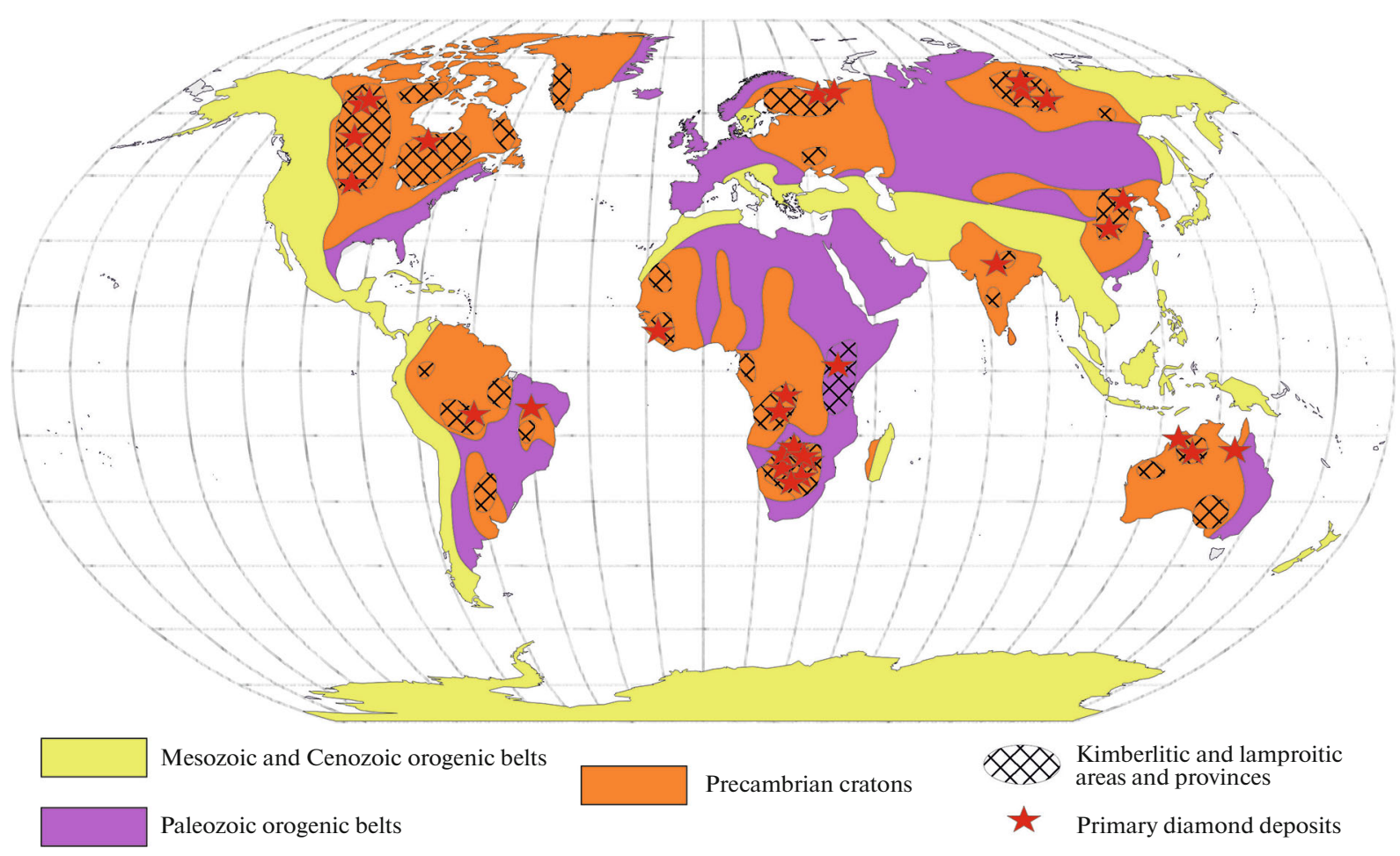

Fig. 1. Distribution of kimberlites and lamproites at the Earth.

found in lamproites (Scott-Smith, 1989). These discoveries significantly expanded promising territories for diamond prospecting, since diamondiferous lamproites and other rocks occur not only within ancient cratons (as do kimberlites) but also in ancient fold belts. At present, dozens of diamond finds have occurred in non-kimberlitic volcanic rocks (Kaminsky, 2007). Diamonds from both non-kimberlitic rocks and mineral inclusions within them seem to be identical to those of kimberlites, and the mechanism of their formation appears to be similar: through disaggregation of mantle ultramafic rocks during formation of lamproites and other non-kimberlitic rocks. Both kimberlites and other volcanic rocks are only diamond carriers.

During this period, diamonds (sometimes in economic concentrations) have also been discovered in rocks sharply differing from kimberlites in composition and genesis, including impactites, metamorphic rocks, ophiolites, and modern volcanic eruptions. Impactites from some astroblemes (Masaitis et al., 1972; Masaitis, 1998, 2013) and metamorphic rocks (Dobrzhinetskaya, 2012) have very high diamond concentrations, an order of magnitude higher than those in kimberlites. Diamonds in chromitites were discovered for the first time in 1980s in China (Fang and Bai, 1981) and are currently found in many ophiolite belts (Yang et al., 2021). Recently, diamonds have been found in the products of modern volcanic eruptions in Kamchatka (Gordeev et al., 2014; Karpov et al., 2014; Galimov et al., 2020). Except for impact diamonds originating from meteorite impacts, the genesis of other diamond types (metamorphic, ophiolite, volcanic) remains controversial. Regardless of exact mechanism, high-pressure diamond crystallization in the mantle is not the only mechanism of diamond formation. Diamond is a polygenetic mineral, and studies of all possible mechanisms and settings underlying its formation are of great scientific and practical significance.

It is impossible to cover in detail all modern concepts on the diamond genesis in the framework of a single journal paper. Our work thus focuses on primary results from recent decades, and on problems of polygenesis of natural diamond. Correspondingly, we are unable to provide all references addressing this subject, and survey only the most significant publications.

\section{DIAMONDS IN KIMBERLITES AND LAMPROITES}

\section{Abundance}

Diamonds from kimberlites and lamproites are the best studied. Among 2500 known kimberlite pipes, only $8-10 \%$ pipes are diamondiferous, and only 25 pipes host economic diamond deposits. Total diamond production worldwide from kimberlites and lamproites is $140-150$ million carats per year. At the beginning of the 20th century, it was approximately one million carats. Kimberlites occur on all known ancient cratons, except for the North African and Ara- 
bian cratons, which, however, harbor diamond placers, suggesting the possible presence of kimberlites (Fig. 1). According to the Clifford's rule, diamondiferous kimberlites are restricted to ancient Archean cratons, archons (Janse, 1994).

\section{Sources of Diamond in Kimberlites and Lamproites}

Diamonds in compositionally different inclusions within kimberlites and lamproites, and paragenetically formed mineral inclusions in diamonds indicate that the primary sources of diamonds are mantle peridotites and eclogites (Sobolev, 1974; Meyer, 1987), and, to a lesser extent, pyroxenites and websterites, from which diamonds were released through partial melting and involved in kimberlite and lamproite magma. Calculated equilibrium conditions indicate that these diamonds were formed at $900-1400^{\circ} \mathrm{C}$, at depths of $150-$ 230 km (Boyd and Finnerty, 1980; Stachel and Harris, 2008; Stachel and Luth, 2015; Stachel, 2014; Nimis et al., 2020). Peridotitic diamonds are formed directly in mantle, whereas eclogitic diamonds are generated both through crystallization of mafic magmas at large depths and during subduction of lithospheric plates to depths within the diamond stability field. As a result, diamonds from different sources have different carbon isotope composition $\left(\delta^{13} \mathrm{C}_{\mathrm{VPDB}}\right)$.

\section{Carbon Sources. Carbon Isotope Composition of Diamonds}

According to the generally accepted concepts, most diamonds' carbon sources are juvenile carbon-bearing $\mathrm{C}-\mathrm{O}-\mathrm{H}$ fluids. This is corroborated by inclusions of high-density carbonate-bearing fluids (Weiss et al., 2014), carbonate minerals and melts (Kaminsky et al., 2016; Logvinova et al., 2019) in diamonds. To a lesser extent, diamond carbon sources include organic compounds from subsiding slabs and metallic media in the lower mantle.

The carbon isotope composition of natural diamonds is the main tool for deciphering their genesis. E.M. Galimov made an important contribution to this question. He determined for the first time the wide variations of carbon isotope composition up to $-32 \%$ o $\delta^{13} \mathrm{C}_{\mathrm{VPDB}}$ in diamonds (Galimov, 1984), and in cooperation with N.V. Sobolev et al., he established differening isotope characteristics of peridotitic and eclogitic diamonds (Sobolev et al., 1979). The carbon isotope variations in diamonds from kimberlites and lamproites measured to date span a wide range from -41 to $+5 \%$ o $\delta^{13} \mathrm{C}_{\mathrm{VPDB}}$ (Cartigny et al., 2014). The majority of values fall in the range from -8 to $-2 \%$ o $\delta^{13} \mathrm{C}_{\mathrm{VPDB}}$, averaging $-5 \pm 1 \%$ o $\delta^{13} \mathrm{C}_{\mathrm{VPDB}}$, which is taken to be the average mantle carbon isotope composition. These values correspond to the isotope composition of peridotitic diamonds. Insignificant variations are caused by carbon isotope fractionation during diamond formation.
According to experimental data, the fractionation of carbon isotopes during diamond crystallization from carbonate fluids is $3.9 \%$, being no more than $4.5 \%$ in the metal-carbon system (Reutsky et al., 2015).

Eclogitic diamonds display much wider $\delta^{13} \mathrm{C}_{\mathrm{VPDB}}$ variations, spanning the entire range from +5 to $-42 \%$, with maximum in the region from -20 to $-28 \%$. This is caused by differing carbonate compound compositions, which undergo subsidence with lithospheric plates at mantle depths, and crystallize there as diamonds, practically without isotope fractionation.

Over $1 \%$ of peridotitic diamonds from South Africa (Deines et al., 1993, 2009, and others; Michael et al., 2010), Arkhangelsk province (Galimov et al., 1994), Brazil (Kaminsky et al., 2001; Bulanova et al., 2010), and Canada (Cartigny et al., 2009) have an anomalous carbon isotope composition $\left(\delta^{13} \mathrm{C}_{\mathrm{VPDB}}=-12\right.$ to $-25 \%$ ) . The cause of this phenomenon remains unclear. Some of these diamonds are likely related to the deep mantle horizons, as is suggested by the presence of iron carbide inclusions. This raises the question of Earth initial carbon isotope composition, given that the $\delta^{13} \mathrm{C}_{\mathrm{VPDB}}$ of chondrite varies from -14 to $-22 \%$ (Wood et al., 2013), while Mars, Vesta, and Moon meteorites have $\delta^{13} C_{\mathrm{VPDB}}=-20 \pm 4 \%$ (Grady et al., 2004). Thereby, the isotope composition of diamond from carbonaceous chondrites varies from -28.0 to $-40.2 \%$ o $\delta^{13} C_{\text {VPDB }}$ (Russel et al., 1996).

\section{Mechanism of Diamond Formation in Different Media}

The majority of diamonds transferred to kimberlites and lamproites from mantle ultramafic rocks were formed through subsolidus metasomatism with the assistance of juvenile $\mathrm{C}-\mathrm{O}-\mathrm{H}$ fluids. According to studies of inclusions in diamonds, the mantle is characterized by reducing conditions, with $\Delta \log f_{\mathrm{O}_{2}}$ varying from fayalite-magnetite-quartz (FMQ) to ironwüstite (IW) buffer and locally even lower (especially in the lower mantle at the contact with core) (Kaminsky et al., 2015). Under these conditions, the $\mathrm{C}-\mathrm{H}-\mathrm{O}$ fluids are mainly made up of water (90-99 mol \%) with a small admixture of $\mathrm{CH}_{4}$ and $\mathrm{CO}_{2}$ (Shirey et al., 2020). The decompression ascent of the mantle with cooling along a geotherm leads to carbon release and isochemical diamond formation, which does not require oxygen exchange with host ultramafic rocks (Stachel and Luth, 2015). At $\Delta \log f_{\mathrm{O}_{2}}(\mathrm{FMQ})=$ $-1.5 \ldots-2.4, T=1140^{\circ} \mathrm{C}$, and $P=5 \mathrm{GPa}$, the following reaction proceeds:

$$
\mathrm{CO}_{2}+\mathrm{CH}_{4} \rightarrow 2 \mathrm{C}+2 \mathrm{H}_{2} \mathrm{O}
$$


Under more reducing conditions $\left(\Delta \log f_{\mathrm{O}_{2}}(\mathrm{FMQ}) \leq\right.$ -3 ), diamond can be crystallized from ascending fluids through the following redox neutral reaction:

$$
2 \mathrm{C}_{2} \mathrm{H}_{6} \rightarrow 3 \mathrm{CH}_{4}+\mathrm{C} \text {. }
$$

Diamond formation in carbonate medium under upper and lower mantle conditions (5.5-8.4 GPa) has been confirmed by experimental methods (Palyanov et al., 2016; Solopova, 2014).

Some kimberlitic diamonds, including the largest ones, contain metallic inclusions of $\mathrm{Fe}-\mathrm{Ni}-\mathrm{C}-\mathrm{S}$ composition, indicating their possible crystallization from a metallic melt with dissolved carbon (Smith et al., 2016a). In addition to the metallic inclusions, the diamonds also contain davemaoite (former $\mathrm{CaSi}$ perovskite), which may indicate their formation in deep Earth. Diamond-forming metallic melts could exist as domains and zones in the lower mantle, especially in the transitional zone $\mathrm{D}^{\prime}$ at the core-mantle boundary. It is noteworthy that in addition to metals, inclusions may be represented by cohenite $\mathrm{Fe}_{3} \mathrm{C}$, which indicates a local carbon oversaturation of the system and could facilitate diamond crystallization.

Data on the carbon isotope composition in these diamonds are interesting. In addition to values of $\delta^{13} \mathrm{C}=-4$ to $-9 \%$ o typical of mantle diamonds, some crystals have a light carbon isotope composition of -25.1 and $-26.9 \%$ (Smith et al., 2016a). It has been hypothesized that this could be evidence of the involvement of crustal carbon in the formation of these diamonds. However, it is possible that such $\delta^{13} \mathrm{C}$ values could be typical of core carbon.

The mechanism of diamond crystallization from $\mathrm{Fe}-\mathrm{Ni}-\mathrm{C}-\mathrm{S}$ melt has been experimentally implemented in the absence (Zhimulev et al., 2012) and presence of a silicate component (Chepurov et al., 2020). Therefore, in diamonds synthesized from metallic melts, metallic inclusions are surrounded by $\mathrm{CH}_{4}$ and $\mathrm{H}_{2}$ fluids (Smith et al., 2016b), as observed in natural diamonds.

Some deposits, in addition to common diamond crystals, contain small $(0.25-0.5 \mathrm{~mm})$ octahedral crystals with flat smoothed faces, usually lacking dissolution traces. These crystals are characterized by a low total nitrogen content (compared to other larger diamonds), with a predominance of $A$-defects (nitrogen atomic pairs). The fraction of aggregated nitrogen $\left(\% \mathrm{~N}_{\mathrm{B}}\right)$ in them is low, near $20 \%$. Such diamonds were found in the kimberlite pipes of the Arkhangelsk province (Palazhchenko, 2008) and in the Madhavan lamproite pipe, India (our observations). We suggest that small octahedral diamond showing no oxidation traces even on the crystal faces were formed at the late stage of kimberlite evolution, already in magma.

Mechanism of diamond crystallization in silicate and silicate-carbonate medium has been experimen- tally confirmed and studied in detail (Litvin, 2009, and references therein).

\section{Depth of Diamond Formation in Kimberlites}

Near $90 \%$ of diamonds are formed in the subcratonic lithospheric mantle (Stachel and Harris, 2008). Thermobarometric calculations for coexisting mineral inclusions show that they crystallized at depths of 150-230 km, averaging 175-180 km (Stachel, 2014; Nimis et al., 2020), indicating that crystallization occurred in the upper mantle. Thereby, diamonds from different deposits have been formed at practically the same depths, however, temperatures estimates deviate from the geotherm to the higher and lower values.

In the 1990s, majorite, bridgmanite, davemaoite (former CaSi-perovskite), ferropericlase, and other minerals were found in diamonds from Brazil (Harte et al., 1999; Kaminsky et al., 2001) and Guinea (Stachel et al., 2000a, 2000b). According to experimental data, these minerals are formed in the transitional mantle zone (220-660 km in depth) and lower mantle (660-2900 km). Reliable geothermobarometers for these associations are absent, and we can only qualitatively estimate that $\mathrm{Fe}$-rich associations are the deepest ones (Kaminsky and Lin, 2017), while diamonds with metallic inclusions could crystallize in the lowest mantle horizons (Smith et al., 2016a).

\section{DIAMONDS IN NONKIMBERLITIC VOLCANIC ROCKS}

Diamond finds in lamprophyres, picrites, and analogous volcanic rocks were hotly debatable several tens of years ago, but at present are a common phenomenon. Within the last 15 years, several dozen known occurrences (Kaminsky, 2007) have been supplemented by diamondiferous lamprophyres in the Nunavut (MacRae et al., 1996; Kaminsky and Sablukov, 2002), Northern Ontario (DeStephano et al., 2006; Wyman et al., 2015), and Northern Quebec (Birkett et al., 2004) provinces of Canada; komatiites of French Guiana (Cartigny, 2010; Smith et al., 2016) and Suriname (Naipal et al., 2019), shoshonite-absarokite-picrites of Uzbekistan (Golovko and Kaminsky, 2010), and others occurrences (Fig. 2). Many of them were found within ancient fold belts instead of ancient cratons. Some of them (in French Guiana and Northern Quebec) are subeconomic deposits.

The most economically promising are ultrabasic lamprophyres subdivided into alnoites (with groundmass melilite), aillikites (with primary carbonate), and damtjernite (with groundmass nepheline and/or alkali feldspar) (Tappe et al., 2005). All types of the lamprophyres contain diamonds. Mineralogically, they are similar to diamonds from kimberlites and lamproites. As in kimberlites and lamproites, diamonds were formed there under high-temperature and high-pressure mantle conditions. The evidence for such mecha- 


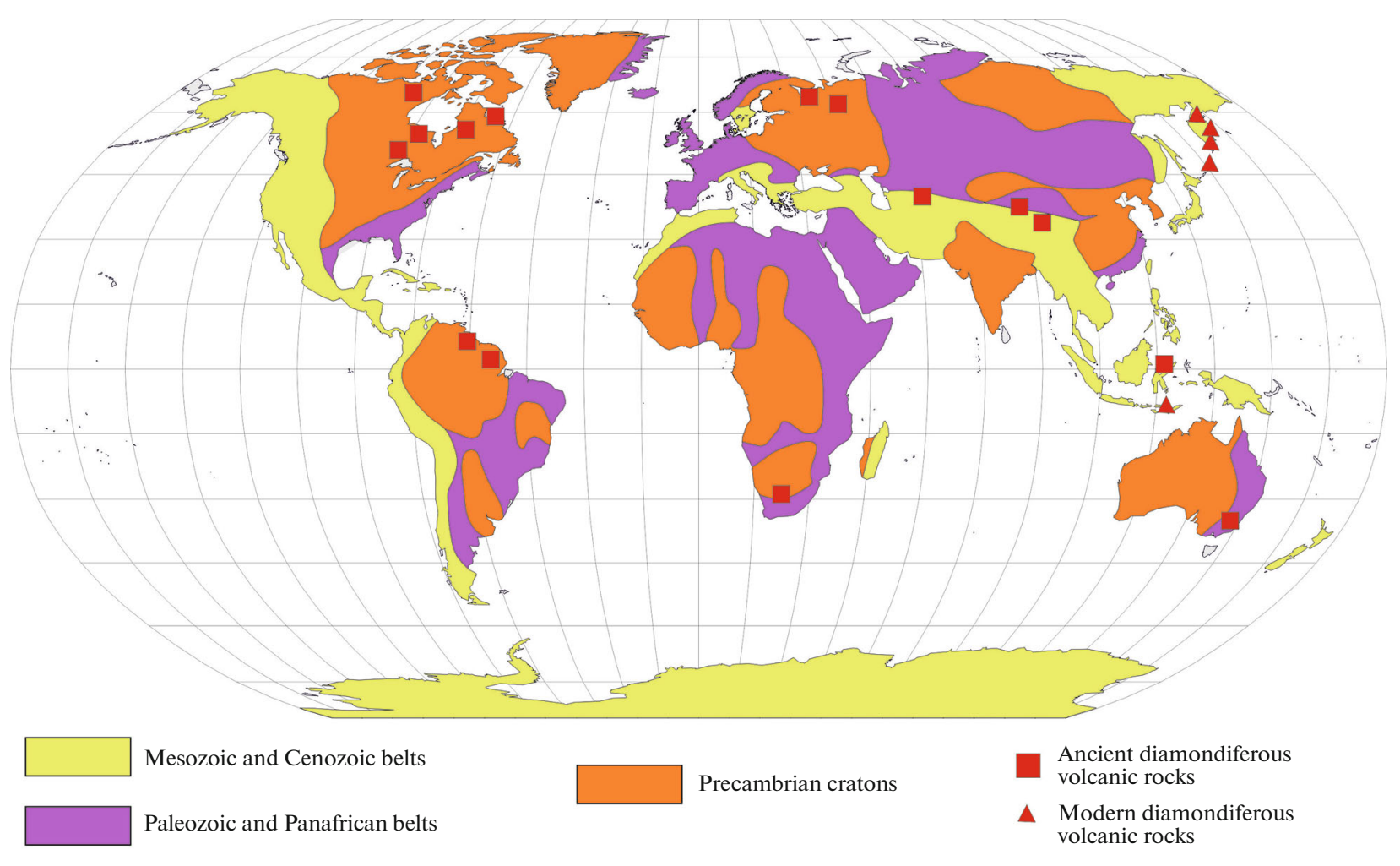

Fig. 2. Distribution of diamondiferous non-kimberlitic volcanic rocks.

nism is the discovery of mantle peridotite xenolith with a diamond inclusion in lamprophyres of North Timan (Kaminsky et al., 1986).

\section{DIAMONDS IN IMPACTITES}

In the early $1970 \mathrm{~s}$, peculiar small $(<1 \mathrm{~mm}$ in size $)$ "laminated" diamond crystals were found in the rocks of the $100-\mathrm{km}$ Popigai meteorite crater (Masaitis et al., 1972). Similar diamonds have subsequently been found in other astroblemes in Russia, Ukraine, Germany, Finland, and Canada (Rost et al., 1978; Valter et al., 1992; Masaitis, 2013, and others), as well as in placers of Ukraine (Polkanov et al., 1973) and Yakutia, where they were called "yakutites" (Kaminsky et al., 1985). They were distinguished as independent XI diamond variety (Orlov and Kaminsky, 1981).

Impact diamonds, in addition to their small size, differ sharply from kimberlitic and lamproitic diamonds in their lamellar morphology, inherited from graphite precursor, microcrystalline texture, and, most significantly, an admixture of hexagonal carbon modification, lonsdaleite, amounting from 5 to $70 \%$. The lonsdaleite admixture impart specific properties to diamonds. Owing to the presence of lonsdaleite and nitrogen aggregation, their abrasive properties are 1.52 times higher than those of common (natural and synthetic) monocrystalline diamonds (Masaitis, 2013).
Galimov et al. (1980) studied carbon isotope composition of impact diamonds, and established that their composition is identical to the isotope composition of graphite in the target rocks of the Popigai crater, confirming that yakutites were formed through graphite recrystallization.

Diamonds have been found in many of 150 astroblemes. Fifteen structures, in addition to the Popigai crater, have been found in Russia. New types of impact diamonds formed through crystallization of coal, and organic remains have been found in the well-studied $\sim 65 \mathrm{~km}$ Kara diamondiferous astrobleme in the Polar Urals (Shumilova, 2021).

Impact diamonds have originated from impact transformation of graphite contained in graphitebearing gneisses (Popigai) or black shales (Kara). They were formed under dynamic compression at temperatures $>1000^{\circ} \mathrm{C}$ and shock loads of 35-60 GPa for approximately half a second, with subsequent relaxation (Masaitis, 1998). The diamond content in impactites can reach economic concentrations (up to 100 carats/ton) at reserves of tens and hundreds of billions of carats, which is many times higher than the world reserves of common "kimberlitic" diamonds. However, at present the profitability of their mining seems to be ambiguous. The main problem facing the study of impact diamonds is the detailed reconstruction of the conditions under which they form, which 


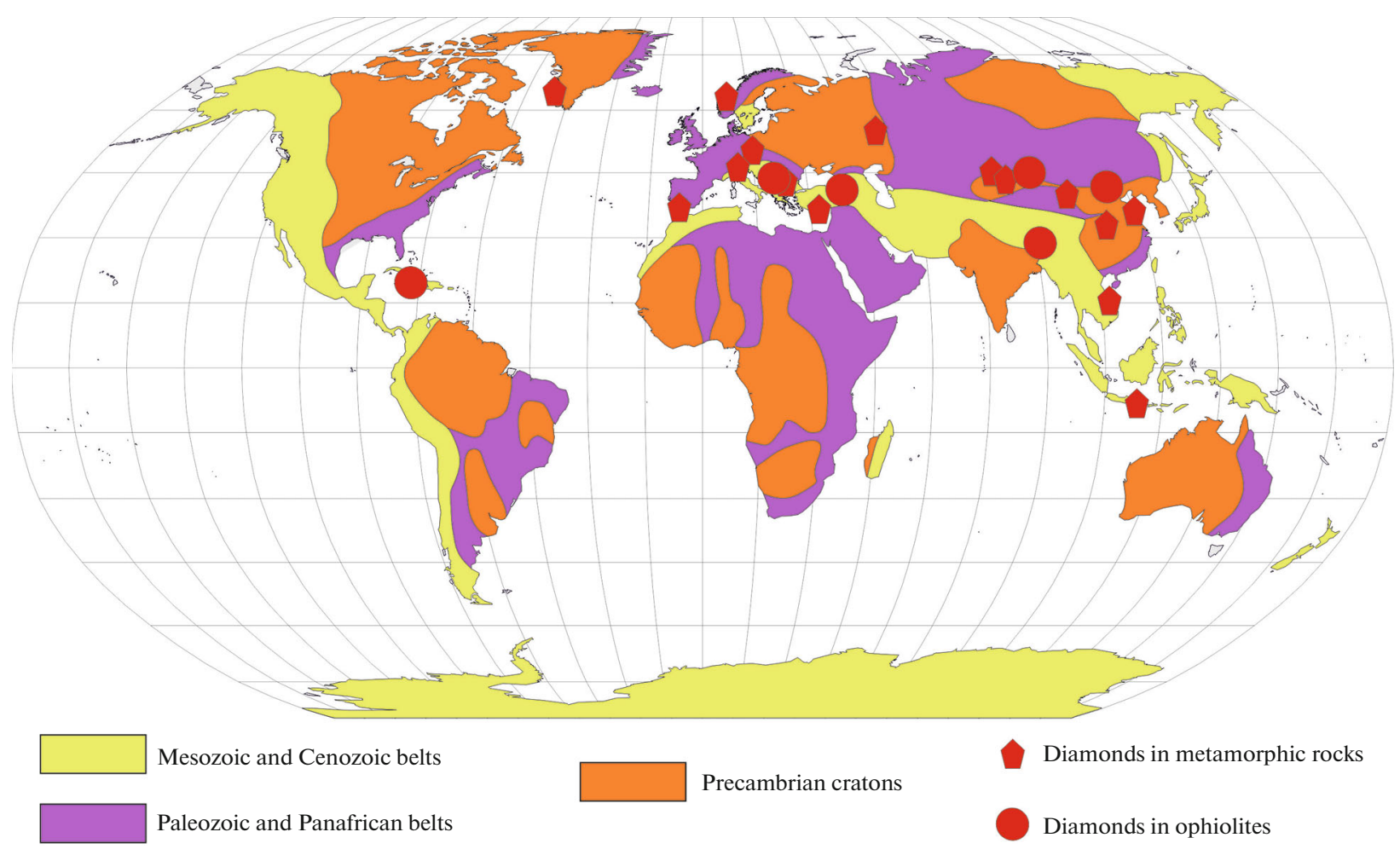

Fig. 3. Distribution of diamondiferous metamorphic rocks and ophiolites.

would allow the economic synthesis of such diamonds with their unique abrasive properties.

\section{DIAMONDS IN METAMORPHIC ROCKS}

In 1970s, diamonds were also found in metamorphic rocks of the Kokchetav Massif, Kazakhstan. Similar diamonds have subsequently been found in many regions worldwide, including in Dabie Shan and Kaidam in China, Norway, Germany, Sulawesi in Indonesia, Greece, South Urals, and other areas (Fig. 3). At the best studied Kumdy-Kol deposit in Kazakhstan, economic diamond concentrations (near 20 carat/ton) have been observed in different lithologies from silicate to essentially carbonate rocks (e.g., Dobrzhinetskaya, 2012). Therefore, metamorphic microdiamonds are frequently present within garnet and zircon grains. As impact diamonds, they are small in size (usually, 100-500 $\mu \mathrm{m}$ ) but contain no lonsdaleite admixture. For this reason, metamorphic diamonds lack high abrasive properties and are thus of no practical interest, although reserves of these diamonds, for instance, in the Kokchetav deposit, reach into the billions of carats.

Several hypotheses (mantle, crustal-mantle, and crustal hypotheses) have been proposed to explain the origin of metamorphic diamonds. The generally accepted model is ultrahigh-pressure metamorphism, where crustal rocks with subduction slabs are submerged deep in the mantle (120-150 km and deeper) reaching the diamond stability field, where diamond is crystallized from carbon-bearing sediments, with subsequent exhumation of the metamorphosed diamondiferous rocks (Sobolev et al., 2003; Liou et al., 2007, 2014; Dobrzhinetskaya et al., 2011). Alternative models suggest fluid-assisted metastable diamond crystallization under subsurface conditions (Pechnikov and Kaminsky, 2008).

\section{DIAMONDS IN OPHIOLITES}

Diamonds were found in ophiolites for the first time in Tibet (Fang and Bai, 1981) and have since been discovered in different regions of the world: in the Inner Mongolia in China, on the Polar Urals in Russia, in Turkey, Armenia, Myanmar, India, Albania, Cuba, and other localities (Fig. 3). In these complexes, diamonds are usually confined to chromitites (Yang et al., 2021).

There is no consensus on the genesis of these diamonds. In particular, the study of minerals in peridotites from Donqiao ophiolites (Tibet, China) has allowed researchers to conclude that diamonds encapsulated in chromite grains were brought up from a depth over $380 \mathrm{~km}$ (Xiong et al., 2017). Some scientists have suggested that such high-pressure peridotites, containing chromite, high-pressure minerals, and minerals requiring highly reducing environment can be formed in mid-ocean ridges (Zhou et al., 2014). Other geologists believe that the presence of the rare 
inclusions of zircon, rutile, and apatite in chromitites indicates their origin in subsiding slabs during subduction (Robinson et al., 2015). Some contemporary hypotheses suggest that chromitites are formed at depths of $\sim 5-10 \mathrm{~km}$ at temperatures within 1050$1200^{\circ} \mathrm{C}$ and pressures $1-1.7 \mathrm{GPa}$ (Ridley, 2013).

Galimov proposed a new model for the diamond formation in chromitites. According to this model, ophiolitic nanodiamonds originate in the deep mantle. Then, nuclei are transported in mantle flows to mid-ocean ridges, where they serve as nuclei for crystallization of larger diamonds, which form in chromitites due to interactions between mid-ocean ridge basalt (MORB) melt and host mantle peridortites (Galimov and Kaminsky, 2021). During subsequent spreading and obduction, these diamonds are exhumed with ophiolite complexes.

\section{DIAMONDS IN MODERN VOLCANIC ROCKS}

Historical data record the discovery of small diamonds in lavas of modern eruptions in Indonesia (Gunung-Ruang Island), but these reports have not received scientific confirmation. In recent decades, such finds have been noted in Kamchatka. Diamonds were found for the first time in the Icha Volcano in the 1970s (Kutyev and Kutyeva, 1975), and were later discovered in the volcanic rocks of the Avacha, Koryaksky, Klyuchevskoy, and Alaid volcanoes (northern Kuril Range). More recently, diamonds have been found in eruption products of the Tolbachik Volcano (Gordeev et al., 2014; Karpov et al., 2014, and others) (Fig. 2).

The volcanic diamonds of Kamchatka include monocrystals, which resemble diamonds from chromitites in morphology, size, and physical properties, and polycrystalline aggregates ("kamchatites"). Detailed complex studies of Tolbachik diamonds have revealed their natural origin (Galimov et al., 2016, 2020). It has been shown that nitrogen in these diamonds was incorporated in a non-aggregated state, while mineral inclusions contain compositionally unique silicide grains. These diamonds also have elevated concentrations of trace halogens $(\mathrm{F}, \mathrm{Cl})$, the distribution of which is similar to that in volcanic gases. This supports the hypothesis that volcanogenic diamonds are formed via a process held in common with diamond formation in the oceanic lithosphere (Galimov and Kaminsky, 2021). It is highly probable that polycrystalline volcanogenic diamonds were formed during eruptions under near-atmospheric pressures by chemical precipitation of gaseous phase (CVD process applied in synthesis of man-made diamonds) (Kaminsky et al., 2016).

The application of technique of diamond extraction from the products of modern eruptions in other volcanic provinces can clarify the conditions and mechanisms of their formation.

\section{FINDS OF DIAMONDS IN OTHER ROCKS UNDER DIFFERENT CONDITIONS}

Diamond finds in nature are not limited by the above-mentioned examples. For instance, microdiamonds have been found in the Akluilak minette dikes (Nunavut territory, Canada) (Kaminsky and Sablukov, 2002) and in the Precambrian greenstone rocks and dikes of the Wawa subprovince (Northern Ontario, Canada) (De Stefano et al., 2006). These diamonds represent nuclei in the diamondiferous roots of ancient continent (Stachel et al., 2006). Nanodiamonds have been found in pyroxene xenoliths from Hawaiian plume products (Wirth and Rocholl, 2003). They may also be diamond nuclei, formed in the oceanic sublithospheric mantle.

The sources and genesis of peculiar polycrystalline diamonds, carbonado, have remained unknown for over two centuries (Kaminsky, 1994).

These occurrences indicate that the diversity of diamond finds is not exhausted, and that discovery of new surprising new diamond sources should be expected with expansion of prospecting works, scientific studies, and analytical techniques.

\section{EXPERIMENTAL AND THEORETICAL PRINCIPLES OF DIAMOND FORMATION}

The above examples of diamond formation suggest different mechanisms of crystallization under terrestrial conditions. Until relatively recently, diamond formation at high temperature and pressure in kimberlites and lamproites has been considered as the only mechanism. This mechanism has been well studied theoretically and experimentally. Figure 4 shows $P-T$ phase diagram for carbon (Bundy, 1996), which is most frequently used to characterize the phase composition of carbon.

This diagram shows equilibrium relationships between thermodynamically stable phases: graphite, diamond, and melt, for one-component "carbon" system, i.e., equilibrium boundaries graphite/diamond, graphite/melt, and diamond/melt (solid lines). The position of the main graphite/diamond boundary is determined using the following equation:

$$
P(T)=\left(2.73 T+2.02 \times 10^{3}\right) \mathrm{MPa} .
$$

However, diamond is not kinetically transformed into graphite under $P-T$ conditions of graphite field, but enters a thermodynamically metastable phase leading up to the short dashed curve. At higher temperatures, the metastable diamond beyond this boundary is transformed into stable graphite approaching the $P-T$ conditions of graphite melting. Thus, in nature, the metastable diamond can coexist with stable graphite. The same kinetic process has been observed for metastable graphite in the diamond stability field. 


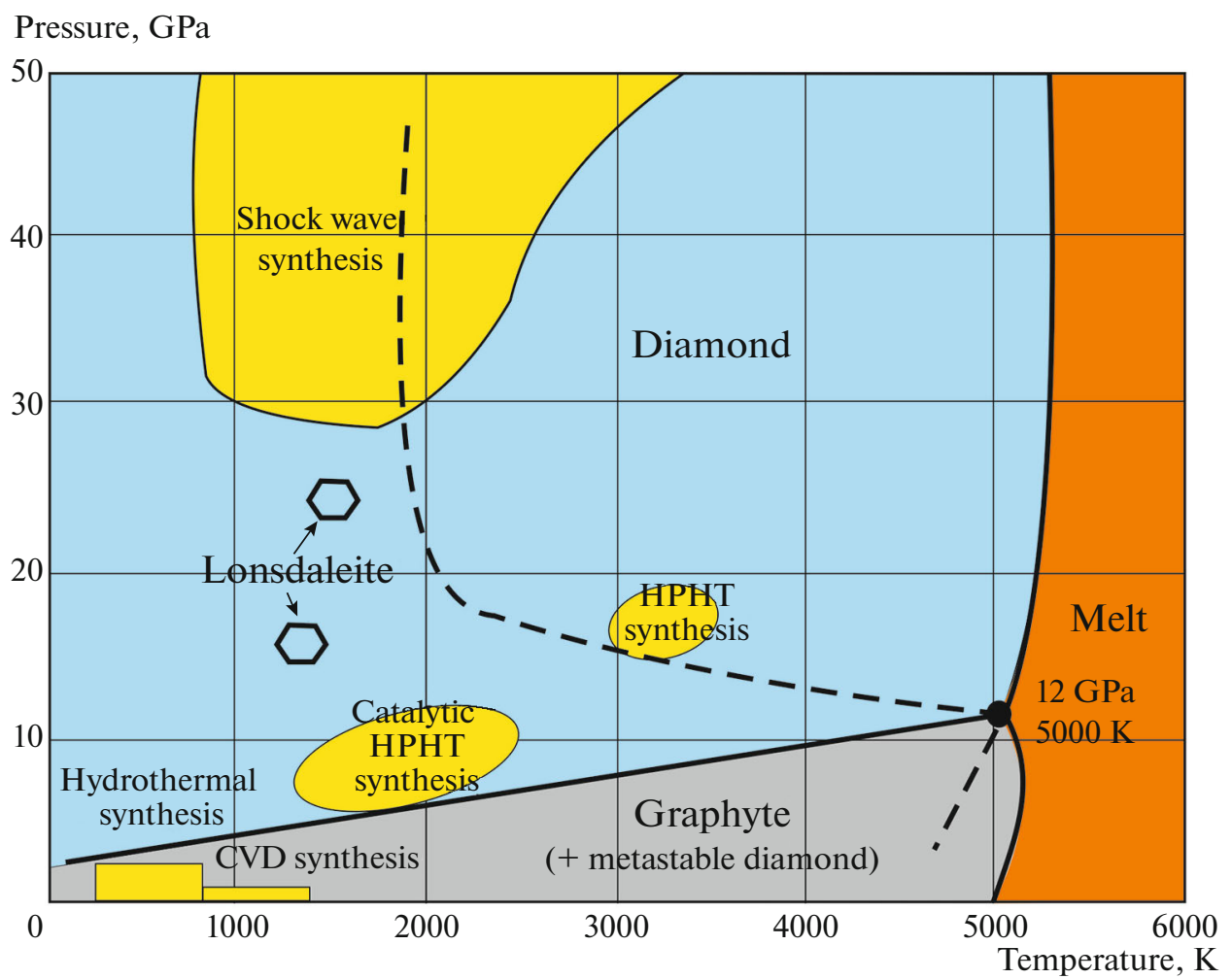

Fig. 4. Phase carbon diagram in $P-T$ coordinates. See text for explanation.

Hexagonal symbols show the $P-T$ fields, where lonsdaleite was synthesized by pulsed heating in a static experiment, or by explosion, under the influence of pulsed pressure and temperature. Thus, "hexagonal diamond" (lonsdaleite) is a "kinetic" product of ductile deformations during diamond forming in nature through the impact process. According to thermodynamic criteria, it represents a metastable phase that is kinetically stable to certain extent. Therefore, it has no own field in the thermodynamic equilibrium diagram.

The enthalpy values for transition of 1 mole of carbon atoms from crystalline diamond and graphite structures into a state of gaseous isolated atoms (enthalpy of atomization) are 713 and $715 \mathrm{~kJ} / \mathrm{mol}$, respectively. Owing to the fact that the mole energy of a diamond lattice is $2 \mathrm{~kJ}$ lower than that of a graphite lattice, diamond can grow in a metastable $P-T$ field together with graphite, especially, in the presence of finest seed serving as a crystallization center. Diamond crystals forming in a metastable field are small in size (nanometers). Therefore, they have only occasionally been found, for instance, in a melt inclusion from garnet peridotite brought to the surface by volcanic products of the Hawaiian plume on Oahu Island (Wirth and Rocholl, 2003).

In the nanosize region, from 3 to $15 \mathrm{~nm}$, a diamond nucleus is a more favorable crystalline form of carbon atoms than graphite. Under disequilibrium conditions, during "quenching", diamond becomes a metastable phase, but a change of crystal lattice could require billions of years. Thus, diamond retains stability against external mechanical influences. Nanodiamond, graphite, and silica carbide were initially found as relict grains-inclusions in carbonaceous chondrites (Lewis et al., 1989) and were later studied in detail (Lavrukhina, 2004). Their stellar origin is indicated by their extremely anomalous nucleogenic isotope compositions and peculiar inert gases compositions. The nanodiamond concentration in a cosmic space can be determined from Table 1.

This phenomenon can be explained by thermodynamic calculations using a previously developed algorithm for studies of nanoparticles (Jiang and Chen, 2006). Three crystalline carbon polymorhs are well known: diamond (D), graphite $(G)$, and fullerene $(F)$. Carbon atoms have $s p^{3}$ (tetrahedral) hybridization in diamond and $s p^{2}$ (trigonal) hybridization in graphite. Therefore, diamond has a 3D structure, whereas graphite consists of two-dimensional carbon layers arranged in an $\mathrm{AB}$ stacking sequence. This sequence differs from the $A B$ sequence in the hexagonal close packed (HCP) structure and is bound by weak Van de Waals $s$-interaction between delocalized $\pi$-orbitals. Under normal conditions and macrosizes $(d)$, graphite is a stable carbon polymorph, and $\mathrm{G} \rightarrow \mathrm{D}$ transition 
Table 1. Main characteristics of interstellar grains of carbon phases in Murchison CM chondrite (after Lavrukhina, 2004)

\begin{tabular}{l|c|c|l}
\hline \multicolumn{1}{c|}{ Phase } & Content, $\mathrm{ppm}$ & Size, $\mu \mathrm{m}$ & \multicolumn{1}{|c}{ Isotope anomalies } \\
\hline Graphite (G) & $<1$ & $1-6$ & $\mathrm{C}, \mathrm{N}, \mathrm{O}, \mathrm{Mg}(\mathrm{Al}), \mathrm{Si}$ \\
Diamond (D) & $\sim 400$ & $\sim 0.002$ & $\mathrm{~N}, \mathrm{Sr}, \mathrm{Ba}$, inert gases \\
$\mathrm{SiC}$ & $\sim 5$ & $\sim 0.2-10$ & $\mathrm{C}, \mathrm{N}, \mathrm{Mg}(\mathrm{Al}), \mathrm{Si}, \mathrm{Ca}$ \\
\hline
\end{tabular}

occurs only at high temperatures and pressures in compliance with the $P-T$ equilibrium phase diagram of carbon (Bundy et al., 1994):

As $d$ decreases to nanometers, diamond can be synthesized at lower temperatures and much lower pressure (Sundqvist, 2021). Thereby, it has been noted that diamond, initially formed at $d<3 \mathrm{~nm}$, transformed into graphite as it grows, indicating a first-order sizedependent phase transition. In addition, with a further decrease in $d$ to $2 \mathrm{~nm}$, the most stable carbon form could be fullerene, as experimentally observed. This phenomenon has been theoretically simulated with various levels of sophistication, from quantummechanical ab initio to thermodynamic calculations (Barnard et al., 2003). Despite the known constraints imposed by thermodynamic considerations, the results show good agreement with experimental data and will be used in our further considerations.

The above-mentioned carbon phase transitions of carbon can be described using the following thermodynamic values: molar surface free energy, $G_{S}$, caused by the surface energy $\gamma$; molar free elastic energy, $G_{E}$, caused by surface tension $f$; and molar Gibbs free volume energy $G_{V}$. Because the difference in free energies of phases $i$ and $j \Delta G^{i-j}(T, d)$ for solid particles displays a complex dependence on temperature $T$ and size $d$, it can be presented in simplified form as a sum of separate members: $\Delta G_{V}^{i-j}(T)$ is the difference of the temperature-dependent molar Gibbs free volume energies; $\Delta G s^{i-j}(d)$ is the difference of the surface molar free energies; and $\Delta G e^{i-j}(d)$ is the difference in molar elastic free energies. Each of these parameters depends only on size (Yang and Li, 2008).

Respectively,

$$
\Delta G^{i-j}(T, d)=\Delta G_{V}^{i-j}(T)+\Delta G_{S}^{i-j}(d)+\Delta G_{E}^{i-j}(d) .
$$

For the sake of simplicity, we suggest that carbon particle with a molar volume $V_{m}$ have spherical shape and are isotropic.

The difference of the molar surface free energies of two phases, $\Delta G_{S}^{i-j}(d)$, can be represented in the following form according to (Zhao et al., 2002):

$$
\Delta G_{S}^{i-j}(d)=A_{m}^{j} \gamma_{m}^{j}-A_{m}^{i} \gamma_{m}^{i},
$$

where $A_{m}$ is the area of the molar phase surface, which can be expressed by the molar volume $V_{m}$ as $A_{m}=6 V_{m} / d$.
The difference of the molar elastic free energy, $\Delta G e^{i-j}(d)$, can be represented as follows:

$$
\Delta G e^{i-j}(d)=P_{m}^{j} V_{m}^{j}-P_{m}^{i} V_{m}^{i}
$$

and is determined by different surface tensions of the two phases. According to the Young-Laplace equation, $P_{m}=f / d$, where $f$ for carbon crystalline phases is determined by equation (Jiang et al., 2001)

$$
f=h\left[\left(S_{v i b} H_{m}\right) /\left(2 k V_{m} R\right)\right]^{1 / 2},
$$

where $R$ is the gas constant; $H_{m}$ is the molar enthalpy of fusion; $S_{v i b}$ is the vibrational term of the total molar entropy of fusion $S_{m} ; k$ is the compressibility; and $h$ is the atomic diameter. Numerical simulation for fullerene $\mathrm{C}_{60}$ using this equation yielded $f=2.36-4.02 \mathrm{~J} / \mathrm{m}^{2}$. Formula (7) yields $f=3.54 \mathrm{~J} / \mathrm{m}^{2}$ (Table 2), consistent with this interval.

At equilibrium between the two phases, $\Delta G^{i-j}(T, d)=$ 0 , and the corresponding critical size of carbon particle $d_{c}^{i-j}(T)$ is determined from equation (4) as follows:

$$
\begin{aligned}
& d_{c}^{i-j}(T)=\left[4\left(f^{i} V_{m}^{i}-f^{j} V_{m}^{j}\right)\right. \\
& \left.+6\left(\gamma^{i} V_{m}^{i}-\gamma^{j} V_{m}^{j}\right)\right] / G_{V}^{i-j}(T) .
\end{aligned}
$$

The value $\Delta G_{V}^{i-j}(T)$ can be determined separately for different pairs of carbon phases: diamond-graphite (D-G), diamond-fullerene (D-F), and graphitefullerene $(\mathrm{G}-\mathrm{F})$. In particular, $\Delta G_{V}^{G-D}(T)$ for the phase

Table 2. Thermodynamic parameters of carbon nanoforms (after Zhao et al., 2002)

\begin{tabular}{l|c|c|c}
\hline \multicolumn{1}{c|}{ Value } & Diamond (D) & Graphite (G) & Fullerene (F) \\
\hline$h, \mathrm{~nm}$ & 0.154 & 0.142 & 0.157 \\
$V_{m}, \mathrm{~cm}^{3} / \mathrm{mole}$ & 3.417 & 5.398 & $2.7 d$ \\
$H_{m}, \mathrm{~kJ} / \mathrm{mole}$ & 125 & 120 & 53 \\
$T_{m}, \mathrm{~K}$ & 3723 & 4800 & 1600 \\
$S_{m}, \mathrm{~J} / \mathrm{mole} \mathrm{K}$ & 33.58 & 25.00 & 33.12 \\
$S_{v i b}, \mathrm{~J} / \mathrm{mole} \mathrm{K}$ & 6.37 & 4.75 & 6.29 \\
$k, 10^{-10} 1 / \mathrm{Pa}$ & 0.088 & 1.000 & 0.212 \\
$E_{c}, \mathrm{~kJ} / \mathrm{mole}$ & - & -714 & -675 \\
$f, \mathrm{~J} / \mathrm{m}^{2}$ & 6.10 & 1.10 & $2 / 98 / d^{1 / 2}$ \\
$\gamma, \mathrm{J} / \mathrm{m}^{2}$ & 3.70 & 3.27 & 0 \\
\hline \multicolumn{4}{r}{}
\end{tabular}




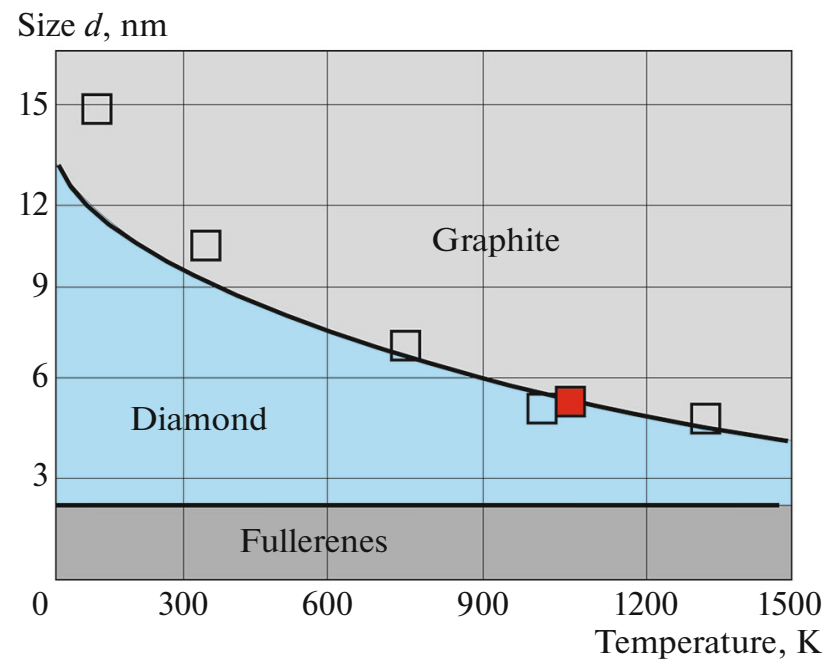

Fig. 5. $d-T$ phase diagram for carbon nanoforms $(P \approx 0)$. Empty boxes show theoretical calculations (Hermann et al., 2001); filled boxes are experimental studies (Yan et al., 2019).

transition $\mathrm{G} \rightarrow \mathrm{D}$ can be estimated from the carbon phase diagram (Bundy et al., 1994) as follows:

$$
\Delta G_{V}^{G-D}(T)=P(T) \Delta V_{n}^{G-D} .
$$

Since fullerene can be considered to be the final two-dimensional analogue of graphite without interlayer attraction and broken edge bonds,

$$
\Delta G_{V}^{D-F}(T)=\Delta G_{V}^{D-G}(T)+\Delta E_{C}^{G-F}(T),
$$

where $\Delta E_{C}^{G-F}(T)$ is the difference of cohesive energy between graphite and fullerene. Note that many isolated structures of complex fullerenes, pentagons, deviate from spherical, and the corresponding thermodynamic parameters for most of them are unavailable, unlike those of $\mathrm{C}_{60}$. The difference of entropies of graphite and fullerene $\mathrm{C}_{60}$ formation can also be ignored in the first approximation, because carbon atoms in both the phases are similarly $s p^{2}$ hybridized.

Thus, thermodynamic considerations allowed us to distinguish a list of physical values for different carbon forms, which are required to specify its phase diagram in the nanosized region. Results of experimental studies (Zhao et al., 2002) are presented in Table 2.

The results of calculations of the $T-d$ diagram for carbon nanoforms according to equation (8) and other related equations are presented in Fig. 5, using parameters from Table 2. The values $d$ for different carbon structures were calculated by normalizing to diamond (D) to obtain clusters of graphite $(G)$ and fullerenes $(F)$ with a number of atoms similar to those of diamond.

Despite some simplifications, the presented thermodynamic semiquantitative model provides a correct description of the phase transitions of carbon nano- forms depending on their size and temperature. A decrease in the energetic barrier to diamond nucleation is mainly caused by changes in surface tension and related surface energy. The $G \rightarrow D$ transition is driven by inner pressure, caused by surface tension $(f)$, which leads to formation of the high-pressure phase, diamond, from nano-sized carbon particle. In turn, the diamond-to-fullerene transition $\mathrm{D} \rightarrow \mathrm{F}$ can be explained by a decrease in surface energy $(\gamma)$. With decreasing size $(d)$, carbon clusters are transformed in the following sequence $\mathrm{G} \rightarrow \mathrm{D} \rightarrow \mathrm{F}$, which correspond to the sequence of bond hybridization $s p^{2} \rightarrow s p^{3} \rightarrow s p^{2}$. In general, the conclusions of thermodynamic model are consistent with available geological, experimental, and theoretical results.

\section{CONCLUSIONS}

This work demonstrates the diversity of different rocks and tectonic conditions in which diamond occurs, and indicates that its formation is not limited to high $P-T$ conditions in kimberlite pipes, as was believed 50 years ago. During these years, economic diamond potential has been established for lamproites, lamprophyres, impactites, and metamorphic rocks. The practical importance of diamonds discovered in ophiolites and volcanic rocks of modern eruptions remains to be estimated. There are also other, more enigmatic diamonds. New diamond discoveries in other rock types and geotectonic conditions have not been excluded.

The formation of diamonds in non-kimberlitic rock types is not always caused by crystallization under stable high temperature and high pressure conditions. Conditions remain ambiguous for metamorphic, ophiolitic, and volcanic diamonds, whose formation is likely related to non-traditional mechanisms. Some geological data indicate the possibility of diamond crystallization outside the $P-T$ diamond stability field.

Thermodynamic considerations and calculations have confirmed this possibility. One of the decisive factors supporting "metastable" diamond crystallization is the size of formed crystallites. The main roles in decreasing the energetic barrier of nucleation for nano-sized diamonds are played by surface tension and related surface energy. As a result, the graphite-todiamond transition is mainly controlled by the internal pressure caused by surface tension, which leads to the formation of high-pressure phase, diamond. These diamond nanocrystals could serve as "seeds", nucleating crystallization of larger diamonds.

Thus, geological and experimental data, confirmed by thermodynamic considerations, indicate that diamond is a polygenetic mineral formed under different physicochemical conditions in different geotectonic settings. Deciphering these conditions is the main task of modern studies, the results of which may be used in 
searching for new diamond deposits and improving techniques for diamond synthesis.

\section{ACKNOWLEDGMENTS}

We are grateful to L.N. Kogarko and O.A. Lukanin for their valuable comments, which have improved the manuscript. We thank Yu.A. Litvin for consultation on diamond synthesis, and A.P. Krivenko and V.S. Fedulova for help with graphics design.

\section{FUNDING}

This work was supported by the Project of Ministry of Science and Higher Education of the Russian Federation (grant no. 13.1902.21.0018, agreement no. 075-15-2020-802).

\section{OPEN ACCESS}

This article is licensed under a Creative Commons Attribution 4.0 International License, which permits use, sharing, adaptation, distribution and reproduction in any medium or format, as long as you give appropriate credit to the original author(s) and the source, provide a link to the Creative Commons license, and indicate if changes were made. The images or other third party material in this article are included in the article's Creative Commons license, unless indicated otherwise in a credit line to the material. If material is not included in the article's Creative Commons license and your intended use is not permitted by statutory regulation or exceeds the permitted use, you will need to obtain permission directly from the copyright holder. To view a copy of this license, visit http://creativecommons.org/licenses/by/4.0/.

\section{REFERENCES}

M. G. Bardet, "Géologie du diamant. Troisième partie: Gisements de diamants d'Asie, d'Amerique, d'Europe et d'Australasie," Bur. Recherch. Géol. Minièr. Mem. 83, 3 (1977).

M. G. Bardet, "Gisements de diamants. Première partie: Généralités," Bur. Recherch. Géol. Minièr. Mem. 83, 1 (1973).

M. G. Bardet, "Gisements de diamants. Deuxième partie: Gisements du diamant d'Afrique," Bur. Recherch. Géol. Minièr. Mem. 83, 2 (1973).

A. S. Barnard, S. P. Russo, and I. K. Snook, "Coexistence of bucky diamond with nanodiamond and fullerene carbon phases," Phys. Rev. B. 68, 073406 (2003).

T. C. Birkett, T. E. McCandless, and C. T. Hood, "Petrology of the Renard igneous bodies: host rocks for diamond in the northern Otish Mountains region, Quebec," Lithos 76, 475-490 (2004).

F. R. Boyd and A. A. Finnerty, "Conditions of origin of natural diamonds of peridotite affinity," J. Geophys. Res.: Solid Earth. 85 (B12), 6911-6918 (1980).

G. P. Bulanova, M. J. Walter, C. B. Smith, S. C. Kohn, L. S. Armstrong, J. Blundy, and L. Gobbo, "Mineral inclusions in sublithospheric diamonds from Collier 4 kimberlite pipe, Juina, Brazil: subducted protoliths, carbonated melts and primary kimberlite magmatism," Contrib. Mineral. Petrol. 160, 489-510 (2010).

F. P. Bundy, W. A. Bassett, M. S. Weathers, R. J. Hemley, H. K. Mao, and A. F. Goncharov, "The pressure-temperature phase and transformation diagram for carbon updated to 1994," Carbon 34, 141-153 (1996).

P. Cartigny, "Mantle-related carbonados? Geochemical insights from diamonds from the Dachine komatiite (French Guiana)," Earth Planet. Sci. Lett. 296, 329339 (2010).

P. Cartigny, J. Farquar, E. Thomassot, J. W. Harris, B. Wing, A. Masterson, K. McKeegan, and T. Stachel, "A mantle origin for Paleoarchean peridotite diamonds from the Panda kimberlite, Slave Province: evidence from ${ }^{13} \mathrm{C},{ }^{15} \mathrm{~N}$ and ${ }^{33-34} \mathrm{~S}$ stable isotope systematics," Lithos 112, 852-864 (2009).

P. Cartigny, M. Palot, E. Thomassot, and J. W. Harris, "Diamond formation: a stable isotope perspective," Annu. Rev. Earth Planet. Sci. 42, 699-732 (2014).

A. Chepurov, V. Sonin, J.-M. Dereppe, and E. Zhimulev, "How do diamonds grow in metal melt together with silicate minerals? An experimental study of diamond morphology," Eur. J. Mineral. 32, 41-55 (2020).

A. De Stefano, N. Lefebvre, and M. Kopylova, "Enigmatic diamonds in Archean calk-alkaline lamprophyres of Wawa, southern Ontario, Canada," Contrib. Mineral. Petrol. 151, 158-173 (2006).

P. Deines, J. W. Harris, and J. J. Gurney, "Depth-related carbon isotope and nitrogen concentration variability in the mantle below the Orapa kimberlite, Botswana, Africa," Geochim. Cosmochim. Acta. 57, 2781-2796 (1993).

P. Deines, T. Stachel, and J. W. Harris, "Systematic regional variations in diamond carbon isotopic composition and inclusion chemistry beneath the Orapa kimberlite cluster, in Botswana," Lithos 112, 776-784 (2009).

L. F. Dobrzhinetskaya, "Microdiamonds-frontier of ultrahigh-pressure metamorphism: a review," Gondwana Res. 21, 207-223 (2012).

L. Dobrzhinetskaya and S. W. Faryad, "Frontiers of ultrahigh-pressure metamorphism: view from field and laboratory," Ultrahigh-Pressure Metamorphism: 25 Years After The Discovery of Coesite and Diamond, Ed. by L. F. Dobrzhinetskaya, S. W. Faryad, S. Wallis, and S. Cuthbert (Elsevier, London, 2011), pp. 1-39.

Q. S. Fang and W. J. Bai "The discovery of alpine-type diamond bearing ultrabasic intrusions in Xizang (Tibet)," Geol. Rev. 27, 455-457 (1981).

E. M. Galimov, "Variations of the diamond isotope composition and their relation with conditions of diamond formation," Geokhimiya, No. 8, 1091-1117 (1984).

E. M. Galimov and F. V. Kaminsky "Diamonds in the oceanic lithosphere. Volcanic diamonds and diamonds in ophiolites," Geochem. Int. 59(1), 1-12 (2021).

E. M. Galimov, F. V. Kaminsky, and I. N. Ivanovskaya, "Study of carbon isotope composition of diamonds of the Urals, Timan, Sayan, Ukraines, and other regions," Geokhimiya, No. 3, 340-349 (1978).

E. M. Galimov, I. N. Ivanovskaya, Yu. A. Klyuev, et al., "Isotope composition and specifics of crystal structure of natural diamond polycrystals with lonsdaleite," Geokhimiya, No. 4, 533-539 (1980). 
E. M. Galimov, O. D. Zakharchenko, K. A. Mal'tsev, A. I. Makhin, and T. A. Pavlenko, "Carbon isotope composition of diamond from kimberlite pipes of the Arkhangelsk region," Geokhimiya, No. 1, 67-73 (1994).

E. M. Galimov, V. S. Sevast'yanov, S. N. Shilobreeva, G. A. Karpov, and A. P. Maksimov, "Diamonds in the products of the 2012-2013 Tolbachik eruption (Kamchatka) and mechanism of their formation," Geochem. Int. 54 (10), 829-833 (2016).

E. M. Galimov, F. V. Kaminsky, G. A. Karpov, et al., "The nature and compositional peculiarities of volcanogenic diamonds," Russ. Geol. Geophys. 61, 1065-1074 (2020).

E. M. Galimov, F. V. Kaminsky, S. N. Shilobreeva, V. S. Sevastyanov, R. Wirth, A. Schreiber, V. V. Saraykin, G. A. Karpov, and L. P. Anikin, "Enigmatic diamonds from the Tolbachik volcano, Kamchatka," Am. Mineral. 105, 498-509 (2020).

V. K. Garanin, "Polygeny and discreteness as fundamental principles of genesis of natural diamond," Problems of Metallogeny, Economic Geology, and Mineral Resources: Scientific-Literature Yearbook, Ed. by V. I. Starostin (MAKS Press, Moscow, 2017), pp. 88-127 [in Russian].

A. Giuliani and D. G. Pearson, "Kimberlites: from deep Earth to diamond mines," Elements 15, 377-380 (2019).

A. V. Golovko and F. V. Kaminsky, "The shoshonite-absarokite-picrite Karashoho pipe, Uzbekistan: An unusual diamond deposit in atypical tectonic environment," Econ. Geol. 105, 825-840 (2010).

E. I. Gordeev, G. A. Karpov, L. P. Anikin, S. V. Krivovichev, S. K. Filatov, A. V. Antonov, and A. A. Ovsyannikov, "Diamonds in lavas of the Tolbachik Fissure Eruption in Kamchatka," Dokl. Earth Sci. 454, 47-49 (2014).

M. M. Grady, A. V. Verchovsky, and I. P. Wright, "Magmatic carbon in Martian meteorites: attempts to constrain the carbon cycle on Mars," Int. J. Astrobiol. 3, 117-124 (2004).

B. Harte, J. W. Harris, M. T. Hutchison, G. R. Watt, and M. C. Wilding, "Lower mantle mineral associations in diamonds from Sao Luiz, Brazil," Mantle Petrology: Field Observations and High Pressure Experimentation, Ed. by Y. Fei, C. M. Bertka, and B. O. Mysen, (Geochemical Society, Huston, 1999), Vol. 6, 125-153.

H. Hermann, F. Fugaciu, and G. Seifert, "Towards controlled production of specific carbon nanostructures theoretical study on structural transformations of graphitic and diamond particles," Appl Phys Lett. 79, 63 (2001).

A. J. A. Janse, "Is Clifford's Rule still valid? Affirmative examples from around the world," Proceedings of the Fifth International Kimberlite Conference 2, Diamonds: Characterization, Genesis, Exploration, Ed. by H. O. A. Meyer and O. Leonardos, (Departamento Nacional da Produção Mineral, Brasilia, 1994), pp. 215-235.

A. L. Jaques, I. D. Kerr, and C. B. Smith "The kimberlites and lamproites of Western Australia," Bull. Geol. Surv. W. Aust. 132, (1986).

Q. Jiang and Z. P. Chen, "Thermodynamic phase stabilities of nanocarbon," Carbon 44, 79-83 (2006).
Q. Jiang, L. H. Liang, and D. S. Zhao, "Lattice contraction and surface stress of FCC nanocrystals," J Phys Chem B. 105, 6275-6277 (2001).

F. V. Kaminsky, Diamond Potential of Non-Kimberlitic Igneous Rocks (Nedra, Moscow, 1984) [in Russian].

F. V. Kaminsky, "Carbonado and yakutite: properties and possible genesis," Proceedings of the Fifth International Kimberlite Conference, Vol.2. Diamonds: Characterization, Genesis and Exploration, Ed. by H. O. A. Meyer and O. Leonardos, (1994), pp. 136-143.

F. V. Kaminsky, "Non-kimberlitic diamondiferous igneous rocks: 25 years after,” J. Geol. Soc. India 259, 557-575 (2007).

F. V. Kaminsky, The Earth's Lower Mantle: Composition and Structure (Springer, 2017).

F. V. Kaminsky, and S. M. Sablukov, "Nontraditional diamond deposits," Nauka v Rossii, No. 1, 4-12 (2002).

F. V. Kaminsky, and J.-F. Lin, Iron partitioning in natural lower-mantle minerals: Toward a chemically heterogeneous lower mantle. Am. Mineral. 102, 824-832 (2017).

F. V. Kaminsky, G. K. Blinova, E. M. Galimov, G. A. Gurkina, Yu. A. Klyuev, L. A. Kodina, V. I. Koptil', V. F. Krivonoc, L. N. Frolova, and A. Ya. Khrenov, "Polycrystallibe diamond aggregates with lonsdaleite from Yakutian placers," Mineral Zh. 7 (1), 27-36 (1985).

F. V. Kaminsky, I. P. Chernyaya, and A. V. Chernyi, "Diamond finds in the alkaline picrites of the alkaline-ultrabasic formation," Mineral. Zh. 8 (2), 39-44 (1986).

F. V. Kaminsky, O. D. Zakharchenko, R. Davies, W. L. Griffin, G. K. Khachatryan-Blinova, and A. A. Shiryaev, "Superdeep diamonds from the Juina area, Mato Grosso State, Brazil," Contrib. Mineral. Petrol. 140, 734-753 (2001).

F. V. Kaminsky, I. D. Ryabchikov, C. McCammon, M. Longo, A. M. Abakumov, S. Turner, and H. Heidari, "Oxidation potential in the Earth's lower mantle as recorded from ferropericlase inclusions in diamond," Earth Planet. Sci. Lett. 417, 49-56 (2015).

F. V. Kaminsky, R. Wirth, L. P. Anikin, L. Morales, and A. Schreiber," "Carbonado-like diamond from the Avacha active volcano in Kamchatka, Russia," Lithos 265, 222-236 (2016).

F. V. Kaminsky, I. D. Ryabchikov, and R. Wirth, "A primary natrocarbonatitic association in the deep Earth," Mineral. Petrol. 110, 387-398 (2016).

G. A. Karpov, V. I. Silaev, L. P. Anikin, V. I. Rakin, E. A. Vasil'ev, S. K. Filatov, V. A. Petrovskii, and G. B. Flerov, "Diamonds and accessory minerals in products of the 2012-2013 Tolbachik Fissure Eruption,” J. Volcanol. Seismol. 8 (6), 323-339 (2014).

A. A. Kukharenko, Diamonds of the Urals (Gosgeolizdat, Moscow, 1955) [in Russian].

F. Sh. Kutyev and G. V. Kutyev, "Diamonds in the basaltic rocks of Kamchatka," Dokl. Akad. Nauk SSSR, 221 (1), 183-186 (1975).

A. K. Lavrukhina, "Interstellar matter in chondrites," Geochem. Int. 42 (8), 697-707 (2004).

R. S. Lewis, E. Anders, and B. T. Draine, "Properties, detectability and origin of interstellar diamonds in meteorites,” Nature 339 (6220), 117-121 (1989). 
J. G. Liou, T. Tsujimori, J. Yang, R. Y. Zhang, and W. G. Ernst, "Recycling of crustal materials through study of ultrahigh-pressure minerals in collisional orogens, ophiolites, and xenoliths: a review," J. Asian Earth Sci. 96, 386-420 (2014).

J. G. Liou, R. Y. Zhang, and W. G. Ernst, "Very high-pressure orogenic garnet peridotites," Proc. Natl. Acad. Sci. 104, 9116-9121 (2007).

Yu. A. Litvin, "The physicochemical conditions of diamond formation in the mantle matter studies," Russ. Geol. Geophys. 50, 1188-1200 (2009).

A. M. Logvinova, A. Shatskiy, R. Wirth, A. A. Tomilenko, S. S. Ugap'eva, and N. V. Sobolev, "Carbonatite melt in type Ia gem diamond," Lithos 342-343, 463-467 (2019).

N. D. MacRae, A. E. Armitage, A. R. Miller, J. C. Roddick, A. L. Jones, and M. P. Mudry, "The diamondiferous Akluilak lamprophyre dyke, Gibson Lake area, N.W.T," Geol. Surv. Canada Open File 3228, 101-108 (1996).

V. L. Masaitis, "Impact diamonds of the Popigai astrobleme: main properties and practical application," Zap. Ross. Mineral. O-va 142 (2), 1-10 (2013).

V. L. Masaitis, "Popigai crater: origin and distribution of diamond-bearing impactites," Meteorit. Planet. Sci. 33, 349-359 (1998).

V. L. Masaitis, S. I. Futergendler, and M. A. Gnevushev, "Diamonds in the Popigai meteorite crater," Zap. Vsesoyuz. Mineral. O-va 101 (1), 108-112 (1972).

H. O. A. Meyer, "Inclusions in diamond," Mantle Xenoliths (Ed. Nixon, P.H.), Chichester: Wiley. (1987), Vol. 1, pp. 501-522.

S. Mikhail, A. P. Jones, S. A. Hunt, C. Guillermier, D. P. Dobson, E. Tomlinson, H. Dan, H. Milledge, I. Franchi, I. Wood, A. Beard, and S. Verchovsky, "Carbon isotope fractionation between $\mathrm{Fe}$-carbide and diamond; a light $\mathrm{C}$ isotope reservoir in the deep Earth and Core?," AGU Fall Meeting (2010), Abstract U21A0001.

R. Naipal, S. Kroonenberg, and P. R. D. Mason, "Ultramafic rocks of the Paleoproterozoic greenstone belt in the Guiana Shield of Suriname, and their mineral potential," Mededeling Geologisch Mijnbouwkundige Dienst Suriname 29, 143-146 (2019).

P. Nimis, R. Preston, S. H. Perritt, and I. L. Chinn, "Diamond's depth distribution systematics," Lithos 376377, Art.: 105729 (2020).

Yu. L. Orlov and F. V. Kaminsky, "Carbonado" with lonsdaleite as a new (XI) variety of polycrystalline diamond aggregates," Dokl. Akad. Nauk SSSR 259, 459-461 (1981).

O. V. Palazhchenko, Extended Abstract of the Candidate's Dissertation in Geology and Mineralogy (MGU, Moscow, 2008).

Y. N. Palyanov, I. N. Kupriyanov, A. G. Sokol, Y. M. Borzdov, and A. F. Khokhryakov, "Effect of $\mathrm{CO}_{2}$ on crystallization and properties of diamond from ultra-alkaline carbonate melt," Lithos 265, 339-350 (2016).

V. A. Pechnikov and F. V. Kaminsky, "Diamond potential of metamorphic rocks in the Kokchetav Massif, Northern Kazakhstan,” Eur. J. Mineral. 20, 395-413 (2008).

Yu. A. Polkanov, G. K. Eremenko, and M. I. Sokhor, "Impact diamonds in fine-grained placers of Ukraine,"
Dokl. Akad Nauk Ukrainian SSR. Ser. B: Geol., Khim., Biol. Nauki, No. 11, 989-990 (1973).

V. Reutsky, Yu. Borzdov, Yu. Palyanov, A. Sokol, and O. Izokh, "Carbon isotope fractionation during experimental crystallisation of diamond from carbonate fluid at mantle conditions," Contrib. Mineral. Petrol. 170 (5-6), 41 (2015).

J. Ridley, Ore Deposit Geology (Cambridge University Press, 2013).

P. T. Robinson, R. B. Trumbull, A. Schmitt, J. S. Yang, J. W. Li, M. F. Zhou, J. Erzinger, S. Dare, and F. H. Xiong, "The origin and significance of crustal minerals in ophiolitic chromitites and peridotites," Gondwana Res. 27, 486-506 (2015).

S. R. Russel, J. W. Arden, and C. T. Pillinger, "A carbon and nitrogen isotope study of diamond from primitive chondrites," Meteorit. Planet. Sci. 31, 343-355 (1996).

B. H. Scott-Smith, "Lamproites, kimberlites in India," Neues Jahrb. Mineral. 161, 193-225 (1989).

S. B. Shirey, K. V. Smit, D. G. Pearson, M. J. Walter, S. Aulbach, F. E. Brenker, H. Bureau, A. D. Burnham, P. Cartigny, T. Chacko, D. J. Frost, E. H. Hauri, D. E. Jacob, S. D. Jacobsen, S. C. Kohn, R. W. Luth, S. Mikhail, O. Navon, F. Nestola, P. Nimis, M. Palot, E. M. Smith, T. Stachel, V. Stagno, A. Steele, R. A. Stern, E. Thomassot, A.R. Thomson, and Y. Weiss, "Diamonds and the mantle geodynamics of carbon deep mantle: carbon evolution from the diamond record," Deep Carbon: Past to Present, Ed. by B. N. Orcutt, I. Daniel, and R. Dasgupta (Cambridge University Press, 2020), pp. 89-128.

T. G. Shumilova, "Giant Kara astrobleme: present state and future frontiers," 52nd Lunar Planet. Sci. Conf. Contrib. (2021) Abs. 2548.

C. B. Smith, M. J. Walter, G. P. Bulanova, S. Mikhail, A. D. Burnhama, L. Gobbo, and S. C. Kohn, "Diamonds from Dachine, French Guiana: a unique record of early Proterozoic subduction," Lithos 265, 82-95 (2016).

E. M. Smith, S. B. Shirey, F. Nestola, E. S. Bullock, J. Wang, S. H. Richardson, and W. Wang, "Large gem diamonds from metallic liquid in Earth's deep mantle," Science 354 (6318), 1403-1405 (2016a).

E. M. Smith and W. Wang "Fluid $\mathrm{CH}_{4}$ and $\mathrm{H}_{2}$ trapped around metallic inclusions in HPHT synthetic diamond," Diam. Relat. Mater. 68, 10-12 (2016b).

N. V. Sobolev, Deep-Seated Inclusions in Kimberlites and Problem of Upper Mantle Composition (Nauka, Novosibirsk, 1974) [in Russian].

N. V. Sobolev, E. M. Galimov, I. N. Ivanovskaya, and E. S. Efimova, "Carbon isotope composition of diamonds bearing crystalline inclusions," Dokl. Akad. Nauk SSSR 249, 1217-1220 (1979).

N. V. Sobolev, V. S. Shatsky, J. G. Liou, R. Y. Zhang, S. L. Hwang, P. Shen, H. T. Chu, T. F. Yui, A. A. Zayachkovsky, and M. A. Kasymov, "US-Russian civilian research and development fund project: An origin of microdiamonds in metamorphic rocks of the Kokchetav Massif, northern Kazakhstan,” Episodes 26, 290294 (2003). 
V. S. Sobolev, Geology of Diamond Deposits of Africa, Australia, Islands of Borneo and North America (Gosgeoltekhizdat, Moscow, 1951) [in Russian].

V. S. Sobolev, "Conditions of formation of diamond deposit," Geol. Geofiz., No. 1, 77-89 (1960).

N. A. Solopova, Extended Abstract of Candidate's Dissertation in Geology and Mineralogy (MGU, Moscow, 2014).

T. Stachel, "Diamonds," Mineral. Ass. Canada Short Course 44, 1-28 (2014).

T. Stachel and R. W. Luth, "Diamond formation - where, when and how?," Lithos. 220-223, 200-220 (2015).

T. Stachel and J. W. Harris, "The origin of cratonic diamonds-constraints from mineral inclusions. Ore Geol. Rev. 34, 5-32 (2008).

T. Stachel, G. P. Brey, and J. W. Harris, "Kankan diamonds (Guinea) I: from the lithosphere down to the transition zone," Contrib. Mineral. Petrol. 140, 1-15 (2000a).

T. Stachel, J. W. Harris, G. P. Brey, and W. Joswig, "Kankan diamonds (Guinea) II: Lower mantle inclusion parageneses," Contrib. Mineral. Petrol. 140, 16-27 (2000b).

T. Stachel, A. Banas, K. Muehlenbachs, S. Kurszlaukis, and E. C. Walker, "Archean diamonds from Wawa (Canada): samples from deep cratonic roots predating cratonization of the Superior Province," Contrib. Mineral. Petrol. 151, 737-750 (2006).

B. Sundqvist, "Carbon under pressure," Phys. Reports 906, 1-53 (2021).

S. Tappe, S. F. Foley, G. A. Jenner, and B. Kjarsgaard, "Integrating ultramafic lamprophyres into the IUGS classification of igneous rocks: Rationale and implications," J. Petrol. 46(9), 1893-1900 (2005).

V. S. Trofimov, Geology of Natural Diamond Deposits (Nedra, Moscow, 1980) [in Russian].

A. A. Val'ter, G. K. Eremenko, V. N. Kvasnitsa, and Yu. A. Polkanov, Impact-Metamorphic Minerals of Carbon (Naukova Dumka, Kiev, 1992) [in Russian].

P. A. Wagner, The Diamond Fields of South Africa (The Transwaal Leader, Johannesbug, 1914).

Y. Weiss, I. Kiflawi, N. Davies, and O. Navon, "High density fluids and the growth of monocrystal in diamonds," Geochim. Cosmochim. Acta 141, 145-159 (2014).

A. F. Williams, The Genesis of Diamond (Ernest Benn Ltd, London, 1932).
R. Wirth and A. Rocholl, "Nano-crystalline diamond from the Earth mantle underneath Hawaii," Earth Planet. Sci. Lett. 211, 357-369 (2003).

B. J. Wood, J. Li, and A. Shahar, "Carbon in the core: Its influence on the properties of core and mantle," Rev. Mineral. Geochem. 75, 231-250 (2013).

D. A. Wyman, P. Hollings, and R. V. Conceição, "Geochemistry and radiogenic isotope characteristics of xenoliths in Archean diamondiferous lamprophyres: Implications for the Superior Province cratonic keel," Lithos 233, 111-130 (2015).

F. Xiong, J. Yang, P. T. Robinson, Y. Dilek, I. Milushi, X. Xu, W. Zhou, Z. Zhang, and H. Rong, "Diamonds discovered from high-Cr podiform chromitites from Bulqiza, eastern Mirdita ophiolite, Albania," Acta Geol. Sin. 91, 455-468 (2017).

X. Yan, X. He, X. Li, X. Wang, H. Yan, X. Xie, and J. Yang, "Kinetics of inverse graphitization of detonation sintered nano-diamond/alumina composites," Ceram. Int. 45, 19596-19609 (2019).

C. Yang and S. Li "Size-dependent temperature-pressure phase diagram of carbon," J. Phys. Chem. C. 112, 1423-1426 (2008).

J. Yang, W. Wu, D. Lian, and H. Rui, "Peridotites, chromitites and diamonds in ophiolites," Nat. Rev. Earth Environ. 2, 198-212 (2021).

D. S. Zhao, M. Zhao, and Q. Jiang, "Size and temperature dependence of nanodiamond-nanographite transition related with surface stress," Diam. Relat. Mater. 11, 234-236 (2002).

E. I. Zhimulev, A. I. Chepurov, E. F. Sinyakova, V. M. Sonin, A. A. Chepurov, and N. P. Pokhilenko, "Diamond crystallization in the $\mathrm{Fe}-\mathrm{Co}-\mathrm{S}-\mathrm{C}$ and $\mathrm{Fe}-\mathrm{Ni}-\mathrm{S}-\mathrm{C}$ systems and the role of sulfide metal melts in the genesis of diamond," Geochem. Int. 50 (3), 205-216 (2012).

M. F. Zhou, P. T. Robinson, B. X. Su, J. F. Gao, J. W. Li, J. S. Yang, and J. Malpas, "Compositions of chromite, associated minerals, and parental magmas of podiform chromite deposits: the role of slab contamination of asthenospheric melts in suprasubduction zone environments," Gondwana Res. 26, 262-283 (2014).

Translated by M. Bogina 